\title{
TACKLING THE MIGRANT WAVE: EU AS A SOURCE AND A MANAGER OF CRISIS
}

\author{
Fulvio ATTINÀ*
}

SUMARY: 1. INTRODUCTION.-2. THE DRIVERS OF THE PRESENT MIGRATION WAVE.3. EUROPE AS A SOURCE OF THE MIGRATION CRISIS.-4. THE EU IMMIGRATION REGIME.-5. THE FIVE PHASES OF THE EU MANAGEMENT.-6. ASSESSMENT OF THE EU MIGRATION CRISIS MANAGEMENT.-7. CONCLUSIONS.

\section{INTRODUCTION}

The domestic conditions of the countries of origin of the migrants are generally assessed as the cause of migration. Ethnic violence, civil conflict, political repression, bad governance, the corruption of the ruling class and public servants, and, above all, the backward stage of the national economy are seen as the undisputed causes of migration. The international sources of migration, instead, draw little attention. The impact of the international economic regimes, the role of international organisations and human rights ideologies, and the synergic impact of these and other features of the world system are understudied by the international studies community.

Migration broke in international studies and course books about 20 years ago. A wave of authors, struck by the breaking of globalization in international affairs, offered a chapter of their books to migration as one of the most troubling issues of globalisation ${ }^{1}$. Generally, the chapters informed about the nature of migration and the increasing number of migrants. Recently, the policies of the global institutions towards migration came to the front ${ }^{2}$ but these works have only a small impact on scholarship. Migration did not go

* Professor of International Relations, University of Catania (attinaf@unict.it).

1 See, for example, Bretherton, C. and Ponton, G. (eds.), Global politics. An introduction, Oxford, Blackwell, 1996; Held, D. and McGrew, A., Global transformations. Politics, Economics and Culture, Polity Press, 1999; SNARR, M. T. and SNARR, N. (eds.), Introducing global issues, Boulder, Lynne Rienner, 2002 and White, B., LitTle, R. and Smith, M., (eds.), Issues in world politics, London, MacMillan, 1997.

2 Attinà, F., The global political system, Basingstoke, Palgrave Macmillan, 2011, and BEEson, M., and Bisley, N. (eds.), Issues in $21^{\text {st }}$ century world politics, Houndsmill, Palgrave MacMillan, 2014. 
on stage as a popular topic of research in international studies. It remains mostly a topic studied by sociologists and demographers. The sources of the increasing wave of migrants and the political response of state governments and international organisations remains an understudied object. While the governments of Europe, North America, and Australia frenetically deal with migration $^{3}$, international law and politics scientists continue to be little concerned with this issue.

In the early Nineties the community of the migration scientists did claim that the age of migration was on, but only recently the phrase management of the migration crisis became a great success in politics and the media. The phrase points out the problem of responding to increasing migration and curbing the negative impact in the inflow countries. The popular saying advises that the immigrants arrive in waves to meaning that migration on occasion turns into an unusual phenomenon. Indeed, migration is normal because always the human beings use either to settle or migrate, and the migrants use either to go and come back to their own country or to delocalize themselves permanently in a foreign country. The phrase migration or migrant wave means that migration turns to being unusual on occasion, $i$. e. on some conditions a huge number of migrants, much larger than the usual one, travel towards a definite area. There is reason to look for knowledge about why a huge number of persons do so, why the routes of normal migration become exceptionally crowded, and why a country or a group of countries are the settlement place most sought by migrants. Similarly, the phrase age of migration means that a set of conditions inexorably raise the size of the migration flows for a long period of time or produce frequent waves of migrants. Migration scientists divide the global and local or macro and micro conditions they label as the causes, drivers, pressures, incentives, or sources of migration. They offer evidence and theories about the causes that are mentioned later in this article, but at this moment, let's go back to the migration wave and migration crisis concepts and elucidate the linkage that exists between the referent objects of the two concepts since this linkage is at the core of the analysis of the response of the EU political leaders and institutions to the current flow of migrants across the Mediterranean Sea.

The policy-makers of the inflow countries respond to the migrant wave by actions and rules aimed at getting through a situation that is not automatically a crisis situation. The right allocation of resources to well-managed policies of reception and integration will certainly reduce the negative effects

\footnotetext{
3 Little, A. and Vaughan-Williams, N., «Stopping boats, saving lives, securing subjects: Humanitarian borders in Europe and Australia», European Journal of International Relations, vol. 23, 2017, num. 3, pp. 533-556; Souire, V., Post/Humanitarian Border Politics Between Mexico and the US, Basingstoke and New York, Palgrave Macmillan, 2015; SouIRE, V., «Governing migration through death in Europe and the US: Identification, burial and the crisis of modern humanism», European Journal of International Relations, vol. 23, 2017, num. 3, pp. 513-532, and WiLliams, J. M, «From humanitarian exceptionalism to contingent care: Care and enforcement at the humanitarian border», Political Geography, vol. 47, 2015, pp. 11-20.
} 
of the arrival of numerous migrants and keep the country within normal life conditions. On the contrary, a migrant inflow turns into a crisis after the citizens perceive the migrants as a threat to normal life conditions before the government starts responding by consequential actions though the effect of the actions is uncertain and the knowledge about the situation is scant. In agreement with this conception of crisis, the situation in Europe turned into a crisis situation after a large number of citizens shared the messages of anti-immigrant groups and parties and perceived the increasing migration wave as a threat. Since the crisis hit all the European countries, the governments decided to coordinate the national response and also develop a common management policy within the European Union.

Certainly, the migrants that arrive to Europe today meet a Europe very much different from the one the migrants met in the past decades. In postWorld War Two, the economies of Western Europe welcomed foreign labour force from countries like Turkey, Morocco and Algeria. In the 1970s, the West European governments turned towards restricting immigration to curb the effects of the world market crisis on the national markets. In the 1990s, irregular migration towards Europe increased enormously after the political change of the Central-Eastern Europe countries and after the effect of the global trends on the economies of the Third world countries. The migration experts warned about the increasing wave of immigrants ${ }^{4}$; the experts of demography ${ }^{5}$ advised about the flywheel effect that the mix of high birth rate, low income level, and missing job opportunities had on migration from Africa; and the students of economic migration ${ }^{6}$ recalled the need of reforming the rules and institutions of the world market to cut the unemployment rate and the number of migrants from the countries of the world periphery.

The wide-range knowledge about the growing pressure of the migration drivers clashes with the lateness of the response of the European policy-makers to the increase of Mediterranean migration in the early 2000s and with the short sightedness of the late response. In 2011, when the number of Mediterranean migrants and drowned persons grew further up, the European leaders were trapped in a sea of doubt and quarrel about how to respond to the phenomenon while they were coping with the post-2008 economic crisis problems, the Greek debt issue, and the increasing wave of extremist and populist parties. These parties blamed the mainstream political parties and the governments for the permissive immigration policies of the past decades

\footnotetext{
${ }^{4}$ Castles, S. and Miller, M., J., The age of migration. International population movements in the modern world, Macmillan, 1993; MASSEY, D. S., et al., Worlds in Motion. Understanding International Migration at the End of the Millennium, Oxford, Clarendon Press, 1998.

5 Hatton, T. J. and Williamson, J. G., The age of mass migration: Causes and economic impact, Oxford University Press, 1998, and KRITZ, M., «Population growth and international migration: is there a link?», Global Migrants, Global Refugees: Problems and Solutions, 2001.

6 Cornelius, W. A., Martin, P. L. and Hollifield, J. F. (eds.), Controlling immigration: a global perspective, Stanford, Stanford University Press, 1995; PIORE, M., Birds of passage. Migrant labour and industrial societies, Cambridge, Cambridge University Press, 1981.
} 
that were worsening the already shattered economy and jeopardizing domestic security. The political leaders responded to the critics by claiming that the blowing number of migrants was mostly the outcome of the unforeseen combination of the poor economic conditions and the high demographic growth of the origin countries with the political uprisings and civil wars that were changing the Middle East and North Africa after the Arab Spring. The governments also reassured the citizens about the determination to dominate the problem through the existing capabilities and to halt the migrants at the border by the available control means. No policy-makers and political party leaders drew attention towards the nature of the flow that apparently was a mixed migration flow or towards the warnings of the experts that had already reached the institutional and public fora of the MSs and the Union.

In line with the foregoing introduction, the baseline argument of the present article is twofold ${ }^{7}$. First, the enlarged wave of migrants towards Europe that has been going on in the past years is driven by global conditions and trends and by the conditions of the countries of origin of the migrants. Second, a migration wave turns into a crisis situation in the countries of destination in the event of some contingencies that produce the citizen perception of the migrants as a threat while the political leaders make no timely, effective and legitimate decisions to both manage the migrant entry and influence the citizen perception. Accordingly, since in the past years the European leaders engaged themselves in responding to the migration wave by developing national response policies and by activating the European Union crisis management capabilities, the objective of the present article is also a twofold objective. First, it wants to develop knowledge about the question whether the European political leaders responded to the enlarged migration wave to follow up to the perception of the large majority of the citizens of the migrants as a threat to the normal conditions of life in their countries. Second, the present article analyses the EU leaders management in order to assess the effectiveness and legitimacy of the outcomes.

The first section of the present article exploits the existing knowledge about the global and local causes of migration and addresses the theme of the drivers of migration in the present world and the increasing wave of migrants towards Europe. The second section faces the issue of why the European citizens and political leaders are hostile to the massive arrival of the people that have left home under the pressure of the global and local causes of migration and want to enter into the EU countries with no legal permit. The third section reviews the immigration regime of the European Union since the Member State (MS) governments decided to manage the migration crisis collectively besides developing their own national response. The fourth section examines the five-phase building process of the EU management of

\footnotetext{
7 This article presents in a condensed manner the findings of a research that has been developed within the Horizon 2020 project named TransCrisis and has been funded by the European Union under grant number 649484. See http://www.transcrisis.eu.
} 
the crisis which has not been a process as timely as expected and did not get to a common strategy as cohesive as it was needed to achieve effective results. The process resulted in the two-pillar architecture of the strict border control and the migration partnership agreements. The fifth and last section assesses the building process and the implementation of the European management of the migration crisis by exploiting an expert model for the analysis of trans boundary crisis management. The concluding section draws the attention towards the flaws of the EU management in coping with the drivers of the increasing wave of migration and in making out durable solutions.

\section{THE DRIVERS OF THE PRESENT MIGRATION WAVE}

The mostly used categories of the present debate about migration are the refugee or asylum seeker, the economic migrant, the forced migrant, and the irregular migrant category. The first and second one are recognised by the meaning they have in international law. The definition of refugee that is stated in the 1951 Refugee Convention works as the universal yardstick of this category of persons ${ }^{8}$. The economic migrant category is stated in national laws and regulations and in the treaties signed by the governments of sending and receiving states. It is also the object of the $1990 \mathrm{UN}$ Convention on the migrant workers ${ }^{9}$. The forced migrant category, an old migration studies concept $^{10}$ and a recognised humanitarian law term, has hit the headlines recently but many in Europe doubt the migrants that cross the Mediterranean are forced to leave their country for escaping hard-to-remove conditions of insecurity, starvation, and deprivation, and for improving their living conditions in a European country. Since forced migrants go unlawfully through the border of states, they are called instead irregular (sometimes illegal) migrants. The regular/irregular migrant dichotomy is specific to the law of the state of entry but, in the current European discourse about migration, the term «irregular migrant» is used as an alias to name all the migrants of the present wave towards Europe. In reality, in the last years, the European leaders blurred the lines between the different categories by tackling all the migrants through almost the same actions. This blurring approach is explained by the argument, explicitly stated by EU documents like the 2016 agreement with

\footnotetext{
8 In the Convention, the term refugee applies to any person who owing to well-founded fear of persecution for reasons of race, religion, nationality, membership of a particular social group or political opinion, is outside the country of his nationality and is unable or, owing to such fear, is unwilling to avail himself of the protection of that country.

9 In the "International Convention on the Protection of the Rights of All Migrant Workers and Members of Their Families», which was approved by the United Nations General Assembly in December 1990, the term "migrant worker» is the person who is to be engaged, is engaged or has been engaged in a remunerated activity in a State of which he or she is not a national.

10 See CASTLES, S., "Toward a sociology of forced migration and social transformation», Sociology, vol. 37, 2003, num. 1, pp. 13-34 and Davenport, C., Moore, W. and PoE, S., "Sometimes you just have to leave: Domestic threats and a migration, 1964-1989", International Interactions, vol. 29, 2003, num. 1, pp. 27-55.
} 
Turkey, that all the migrants should stay home, and the refugees should go to countries on the border of their home country since the pressure to migrate is the effect of events, conditions and problems of local range and temporary duration that will be removed by international cooperation programmes. But the opinion of the experts does not fit to such argument.

Migration researchers assert that, in contemporary times, bad governance, violence, corruption, and civil wars, not to mention the ever-existing ethnic and cultural differences that were ignored or underestimated at the time of the decolonisation and the building of the states, push people to seek better life conditions elsewhere out of the home country ${ }^{11}$. Furthermore, in almost all the countries of the periphery of the world economy, the shortage of financial and industrial resources that existed at the time of the rebuilding of the world economic regimes after the Second World War has not been changed by the aid to development that has been given by the rich countries for the last sixty year. On the contrary, the dependent economy of these countries fell down under the effect of the unfavourable rules of the world economic regimes, the climate change shocks, and the persistence of political instability, inefficient administration, and corrupt civil servants. In addition to the local conditions, the present migration wave is the outcome of incentives and drivers that impact on all the countries and especially on those of the weakest areas of the world.

The current migration wave is the first to come out of an unprecedented mix of local and global conditions ${ }^{12}$. The sources of the current wave are rooted in the structure of the world capitalist economy that is quite different from the traditional one. In the post-World War Two world, the joint effect of the economic policies and international treaties of the richest countries and the rules and programmes of the world economic, trade, and financial institutions extended the gap between the rich and poor economies and soured the economic sources of migration. Later, new features and trends came into play. Technological advancement upgraded the role of transportation and communication means as drivers and incentives of migration. Small and fast transportation means reduce the time of relocation and enable migrants to travel almost hidden to the authorities, frequently with the support of smugglers ${ }^{13}$. Cell phones and the web ${ }^{14}$ provide to the potential migrant with instanta-

11 AFIFI, T., «Economic or environmental migration? The push factors in Niger», International Migration, vol. 49, 2011, num. 1, pp. 95-124; CASTLES, S., op. cit., nota 10, p. XX; DavenPort, C., Moore, W. and Poe, S., op. cit., nota 10, p. xx, and GiBney, M., ApodacA, C. and McCANN, J., «Refugee flows, the internally displaced and political violence (1980-1993): An exploratory analysis», Wither refugee, 1996, pp. 45-66.

12 Attinà, F., «Migration drivers, the EU external migration policy and crisis management», Romanian Journal of European Affairs, vol. 16, 2016, num. 4, pp. 15-31.

13 YILDIZ, A., Perception of smuggling business and decision-making processes of migrants, Ankara, IOM, 2017.

14 Koen, L. and Smets, K., «Five Questions for Digital Migration Studies: Learning From Digital Connectivity and Forced Migration In(to) Europe», Social Media + Society, vol. 4, 2018, num. 1, pp. 1-16. 
neous information about job and welfare opportunities in foreign countries and about the fast transportation means and routes to go for crossing state borders with no entry permit. Moreover, digital communication keeps the migrant connected to the family and home community; lessens the human costs of breaking personal relationships; enables the migrants to keep their own identity in countries of different culture; and promotes business transnationalism ${ }^{15}$. These technological conditions give strong sustain to the personal linkages that diaspora studies ${ }^{16}$ and the network theory of migration ${ }^{17}$ consider the determinant of the decision to reach the country of settlement of relatives and community peers also if in this country job opportunities are missing. The growing demographic gap between rich areas like Europe and poor areas like Africa is a further source of migration, and is enlarged by the climate change damages that worsen the living conditions of the overpopulated areas. The diffusion of human rights by international organisations and civil society groups is an incentive to migrate towards countries that protect human rights. The UN agencies and international organisations of human rights promote migration by their own and in partnership with non-governmental organisations. They also do their best to push the governments of potential destination countries to comply with the human right of migration in normal and especially in exceptional circumstances since the treaties were conceived mainly for coping with such circumstances. Last, also today smugglers and crime organisations, civil society associations, and ordinary citizens provide services to migrants and play incentives to migration. Smugglers assist migrants to bypass barriers for profit and often with little regard for the well-being of the migrant. Experts assess migrant smuggling as a complex service that is operated by different types of actors including single individuals and crime organisations. Governments blame smuggling organisations for being a major incentive to irregular migration. Experts, instead, blame restrictions and absence of legal channels for building the flourishing conditions of smuggling ${ }^{18}$. In the countries of destination, civil society associations and ordinary citizens provide services to migrants either for moral reasons or profit, and play as intermediaries between the migrants and the receiving state $^{19}$. Their action cannot be overestimated. The policies for promoting the integration of the migrants and building multiculturalism to easy the meet-

15 CASTLES, S., «The Factors That Make and Unmake Migration Policies», International Migration Review, vol. 38, 2004, num. 3, pp. 852-884, and Vertovec, S., «Migrant Transnationalism and Modes of Transformation», International Migration Review, vol. 38, 2004, num. 3, pp. 970-1001.

16 Délano, A. and Mylonas, H., «The microfoundations of diaspora politics: unpacking the state and disaggregating the diaspora», Journal of Ethnic and Migration Studies, 2017, and FAwCETT, J., «Linkages and migration systems», International Migration Review, vol. 23, 1989, num. 3, pp. 671-680.

17 Epstein, G. S. and GANG, I. N., "The influence of others on migration plans», Review of Development Economics, vol. 10, 2006, num. 4, pp. 652-665, and MASSEY, D. S. and GARCIA-EsPanA, F., «The social process of international migration», Science, vol. 237 (4816), 1987, pp. 733-738.

18 Garelli, G. and Tazzioli, M., "The Humanitarian War Against Migrant Smugglers at Sea, Antipode», vol. 00, 2017, num. 0, pp. 1-19, and TinTI, P. and Reitano T., Migrant, Refugee, Smuggler, Savior, Oxford, Oxford University Press, 2017.

19 Ambrosini, M., "Why irregular migrants arrive and remain: the role of intermediaries», Journal of Ethnic and Migration Studies, vol. 43, 2017, num. 11, pp. 1813-1830. 
ing of the immigrants and the citizens of the receiving country that some European countries experimented in the last decades of the past century turned against this objective and into a cause of social conflict ${ }^{20}$. Therefore, to explain why the current migration wave turned into a crisis, the analysis will address cultural and other domestic matters of the receiving states. The next two sections address this theme in a holistic perspective. In the next section, the focus is on the response to migration by the states and societies of Europe as a whole. In the following section, the focus is on the regime that has been developed by the EU institutions to face migration.

\section{EUROPE AS A SOURCE OF THE MIGRATION CRISIS}

Europeans welcome non-EU workers, especially those bearing job skills, on condition that they sign the labour contract and accept moving out of Europe as soon as the contract expires. In addition to temporary and circular economic migrants, Europeans welcome refugees and asylum seekers from areas of undisputed conditions of political persecution and war. In today Europe, any other migrant is unwanted and is perceived as a threat to the security, economy, and culture of the receiving country. In the past, instead, the perception of the immigrants was a less negative and rather blurred one.

In the second half of the past century, former colonial states like France, the United Kingdom and the Netherlands accepted and integrated the people of the colonies. Prosperous countries like Sweden, and countries with a growing economy like Germany managed to receive workers from European and non-European countries. Each country set up own reception and integration policies. Some tried multiculturalism but failed. Generally, the European governments ruled about the reception and integration of regular and irregular immigrants by making rules and organising programmes in collaboration with business and trade unions and with religious and civil society groups, the so-called client politics ${ }^{21}$. Additionally, there was no strong opposition to the government regulations that allowed to irregular migrants to stay in the country and legalise their status, the so-called permissive policies ${ }^{22}$. Client politics went unopposed because the permissive measures let the foreign workers fill in the jobs available in the economic sectors of low-profit margins and in the industrial sectors that could not be delocalized to countries of low labour costs. The Europeans usually refused to take such jobs. Also popula-

\footnotetext{
20 Vertovec, S. and Wessendorf, S. (eds.), The multiculturalism backlash: European discourses, policies and practices, London, Routledge, 2010.

21 Hansen, R., «Migration to Europe since 1945: its history and its lessons», The Political Quarterly, vol. 74, 2003, num. 1, pp. 25-38.

22 Baldwin-Edwards, M. and Kraler, A. (eds.), Regine - Regularisations in Europe, Amsterdam, Amsterdam University Press. - cdm. 2009; BRICK, K., Regularization in the European Union: The contentious policy tool, Washington, DC: The Migration Policy Institute, 2011, and Mc Govern, C., Regularization programs within the European Union: an effective tool to manage irregular migration?, Barcelona, UNU-CGM, Policy report, 2014.
} 
tion aging played a strong role in raising the demand for immigrant workers. These labour conditions exist also today in sectors like the agriculture, fishing, constructions, mining, caregiving and nursing, cleaning, caring and hospitality sector.

The media used to inform about migration politics in the European countries by distinguishing the right-wing parties as anti-immigration and anti-integrationist actors, and the left-wing parties as pro-immigration and integrationist actors. The analyses of the political scientists drew a different picture. The right wing and centrist parties did not straight oppose immigration because they wanted to satisfy the business lobbies demand for cheap labour force. The left-wing parties, in agreement with the trade unions, looked carefully at immigration since it could affect the wage and employment opportunity of the native workers ${ }^{23}$. Furthermore, in the analysis of the political scientists the line between Left and Right disappears since the stage of economic growth, the level of unemployment, the size of previous immigration in the country, and alike issues are on the agenda of the policy-makers. Briefly, the difference between left-wing and right-wing parties ends when entry and immigration control rather than integration issues come into deliberation ${ }^{24}$. Therefore, it is not surprising that, since crisis broke into the economic policies of the European countries in 2008, all the parties have asked for tightening the rules of entry permit and for curbing all forms of immigration.

The experts of immigration policies remark especially that the agreement between all the political parties on anti-immigration has been the effect of the recognition and endorsement of the perception of physical security threat that took over the image of the immigrants as a menace to the interests of the local workers. Lahav and Messina argue that the inability of states to manage immigration unilaterally and effectively -while responding adequately to growing public insecurity - has led to greater bilateral and multilateral efforts to restrict the flow of persons, and especially asylum-seekers and illegal migrants, across national borders with the support of left, centre and right parties ${ }^{25}$. Under the pressure of the media and the radical and populist parties, the mainstream parties took a harder-line to respond to the demand of their own members and the voters. They decided to end the permissive immigration policies that had been made to please the business lobbies and civil society groups $^{26}$. De Haas and Natter, then, come to the conclusion that, in present

23 Hinnfors, J., Spehar, A. and Bucken-Knapp, G., "The missing factor: why social democracy can lead to restrictive immigration policy», Journal of European Public Policy, vol. 19, 2012, num. 4, pp. 585-603, and Hix, S. and Noury, A., «Politics, Not Economic Interests: Determinants of Migration Policies in the European Union», International Migration Review, vol. 41, 2007, num. 1, pp. 182-205.

24 De HaAs, H. and NatTer, K., The determinants of migration policies. Does the political orientation of governments matter? DEMIG project paper 29, 2015 (www.imi.ox.ac.uk).

${ }_{25}$ Lahav, G. and Messina, A. M., "The Limits of a European Immigration Policy: Elite Opinion and Agendas within the European Parliament», Journal of Common Market Studies, vol. 43, 2005, num. 4, pp. 851-875, pp. 851-852.

${ }^{26}$ Han KYUnG, J., "When Will Left-Wing Governments Introduce Liberal Migration Policies? An Implication of Power Resources Theory», International Studies Quarterly, 2014, pp. 1-13, and BALE, T., 
time Europe, there is no clear association between the political orientation of governments and the restrictiveness of migration policies since all mainstream political parties share the same position about irregular migration (2015: 2). Briefly, in all the European countries, migration shifted out of client politics into the field of public politics, the politics characterised by public salience, polarization, and actor expansion ${ }^{27}$. Economic, cultural, and security arguments have been widely used to explain such change. In brief, the large wave of migrants is a big burden to the budget of the receiving state and an overload to the national welfare system. These costs look unaffordable to the citizens and taxpayers that oppose to sharing life with «others» that bring in external cultures. Finally, the real or perceived growth of street crime and the infiltration of criminal networks and terrorist groups are also perceived as related to immigration.

The political salience of migration, boosted by the success of the populist parties and anti-immigration groups, pushed all political parties to gain a visible role in policy-making towards migration. All mainstream parties positioned themselves on restrictive immigration policies in order to respond to the voter hostility to migration and to face the electoral rise of the populist parties. Only a few opposition parties, mostly on the left-hand side of the party system, remained silent on restrictive immigration policies.

In conclusion, opposition to permissive immigration policy and to client politics existed in the past but after the 2008 economic and financial crisis the anti-migrant and xenophobic parties got a remarkable electoral success. Consequently, in total disdain of the foreign labour needs of the European economies and households, the governments and mainstream parties ceased to be permissive towards irregular immigrants, approached migration as a public politics issue, and turned to halting immigration by passing restrictive rules $^{28}$. This occurred at the time the Arab Spring added a lot of refugees to the multiyear-long inflow of irregular migrants. Meeting the migration wave that originates from global and distant local causes, Europe became a source

\footnotetext{
"Turning round the telescope. Centre-right parties and immigration and integration policy in Europe», Journal of European Public Policy, vol. 15, 2008, num. 3, pp. 315-330.

27 DE BRUYCKER, I., "Politicization and the public interest: When do the elites in Brussels address public interests in EU policy debates?», European Union Politics, 2017, pp. 1-17. He describes these features of public politics as follows. Public salience is the importance that public opinion attributes to a specific issue. It pushes political elites to address the issue and craft claims about it. Polarization is the high disagreement and conflict existing among different groups of stakeholders on specific aspects of the issues. It pushes political elites to appeal to the public interest to defend their position. Actor expansion is the mobilization of civil society groups that makes political elites prone to appeal to public interest, pp. 3-4.

${ }^{28}$ In 2012, the year that followed the growth in number of the irregular migrants crossing the Mediterranean, the EU countries experienced $12 \%$ decrease of regular migration of non-EU nationals. The decrease was the effect of the tightening of the number of immigration visas that was developed by the European MS border agencies. CréPEAU, F., and Purkey, A., Facilitating Mobility and Fostering Diversity. Getting EU Migration Governance to Respect the Human Rights of Migrants, Brussels, CEPS Paper in Liberty and Security in Europe, 2016, num. 92, p. 3. Unsurprisingly, in that year and the following ones, the number of irregular migrants in Europe grew enormously.
} 
of the migration crisis in her own territory because the citizens, struck by economic decline and public expenditure cuts, shared the anti-immigration messages of the populist parties while the policy-makers were unprepared to respond to that pressure by normal political means rather than by crisis management responses. At the same time, the EU institutions and the MS governments put themselves up in the role of manager of the crisis. They did it by national instruments and policies and agreed to develop collective management at the EU level. This has been a hard task. Moreover, the MS governments hindered the EU's attempt to act as the main caretaker of the migration wave.

\section{THE EU IMMIGRATION REGIME}

In the past fifteen years, the EU countries have been reducing the protection of immigrant rights as a response to domestic demands and interests. Though the immigration regime of the MSs is linked to the common regime they have shaped within the $\mathrm{EU}^{29}$, the states preserve the power of legislating the social and economic integration of foreign workers against the European Commission's preference for the free movement of labour in the name of economic efficiency. However, the EU directives on the protection of immigrant rights profit from the institutional protection existing in the MSs such as a strong court system, legal aid for immigrants, and state funding for pro migrant $\mathrm{NGOs}^{30}$. Much important to the present analysis, the EU created a regime for managing migration outside her own borders in order to avoid irregular immigration. This regime comprises $a$ ) norms and mechanisms for coordinating border control, and $b$ ) the EU external migration policy that has been developed by the Commission and approved by the Council and the Parliament.

Border control is in the power of the MSs but the EU plays a role. At the policy making level, the EU sets standard and makes rules on selected issues. At the operational level, the EU provides assistance to the MS governments and promotes the coordination and convergence of the border control agencies of the MSs. The EU regime came into effect since the Treaty of the European Union incorporated the Schengen system that sets the criteria the MSs apply to grant permission of entry and to reside in their territory to thirdcountry nationals. FRONTEX and EASO are the EU agencies mandated to provide assistance and coordination and to promote the convergence of the MS models of border control against security threats and irregular immigration. FRONTEX, created in 2004, coordinates the MS management of the external borders ${ }^{31}$. In 2017, it incorporated the mission of the new created

\footnotetext{
${ }^{29}$ The immigration regime of a state is the set of criteria, norms and policies that define who is allowed to enter and who is not, and accordingly manage the control of the borders.

30 LuedtKe, A., «Uncovering European Union Immigration Legislation: Policy Dynamics and Outcomes», International Migration, vol. 49, 2011, num. 2, pp. 1-27.

31 The full name of the Agency is the European Agency for the Management of Operational Cooperation at the External Borders of the Member States of the European Union.
} 
European border and coast guard service. EASO, the European Asylum Support Office that was created in 2011, provides information to the EU institutions and the MS governments about the management of migration problems in general and the refugees and asylum seekers in particular.

The external migration policy is aimed at governing the entry of immigrants in the EU by means of actions and programmes realised beyond the EU borders and in collaboration with external actors and third parties. The Commission presented this policy in the 2005 Communication titled Global Approach to Migration, and upgraded it in 2011 to meet the challenge of the growing migratory flows from nearby areas. The 2011 Communication is titled Global approach to migration and mobility and is known by the acronym GAMM $^{32}$. Complementing the term migration with the term mobility is a meaningful act. To the EU leaders, migrants are allowed to stay in a EU country only the time of the job contract. Accordingly, mobility is the synonym of circular and temporary migration, and is valued as the essential condition of the economic efficiency of migration. In the GAMM document, migration is an economic phenomenon, and the migrant is the person that moves from a country of very little or no economic growth and job opportunities to a country of growing economy and large job opportunities. The receiving country profits from the migrant manpower to feed its growing economy. The economy of the sending country profits from the migrant remittances to sustain its weak economy. The advantage of the two parties is achieved on condition that migration is well managed by the political authorities of the sending and receiving countries. Well-managed migration is made through migration agreements between the governments of the sending and receiving country and by firmly implementing the agreement clauses on the return of migrants to the sending country when jobs are no longer available in the hosting country. Accordingly, the government of both the receiving and sending states must stay firm against irregular migration because it inhibits wellmanaged migration. Therefore, the government of the country of entry and the country of origin will agree on readmission clauses and implement all the migration, mobility and border control norms of the treaties they sign to reach the economic efficiency of migration.

The EU institutions, especially the Commission, promote the external migration policy in the belief that it is necessary to supplement the border control measures of the MSs by a network of cooperation agreements with the countries of origin and transit of the migrants that address mobility and reduce the costs of the MSs to return and obtain the readmission of irregular migrants to the home country ${ }^{33}$. The Commission is involved also in develop-

32 GAMM and the external migration policy have been confirmed in February 2014 when the Commission released to the other EU institutions the Communication reporting on the implementation of the Global Approach to Migration and Mobility 2012-2013 [Com (2014) 96 final].

33 Seeberg, P., «Mobility Partnerships and Security Subcomplexes in the Mediterranean: The Strategic Role of Migration and the European Union's Foreign and Security Policies Towards the MENA Region", European Foreign Affairs Review, vol. 22, 2017, num. 1, pp. 91-110. 
ing regional forums and dialogues like the EU-Africa Strategic Partnership, the Prague Process, the Khartoum Process, and the Rabat Process that aim at managing migration on a broad geographical base.

The external migration policy meets with problems and obstacles. Stemming the outflow of migrants is rarely in the economic and political interest of the governments of the countries of departure of migrants. Migration is a vital source of income. Migrant remittances constitute a huge income source, larger than the amount of the received development assistance funds. To some governments, migration is also a safety valve of domestic stability since unemployed people foment political protest and turmoil, and are a threat to the existing political regime. Furthermore, the governments of these countries are not equipped to accomplish all the tasks stated by the mobility partnership agreements. Inefficiency and corruption are widespread in the public service and make the building of the migration control capabilities a long and inefficient process. The control of the central government on the periphery regions is seldom an effective one due to conflict with the local authorities. Finally, these agreements are not legally binding, do not have provisions for assessing accomplishment by the partner country, and do not bind the EU governments that did not sign the documents.

\section{THE FIVE PHASES OF THE EU MANAGEMENT}

In this section, the analysis focuses on how the EU institutions and governments have tackled the inflow of migrants since 2011 in harmony with the common immigration regime. In 2011, the number of irregular migrants unloaded by smuggler boats on the coasts of the EU Mediterranean countries, a long-time existing phenomenon, increased considerably compared to the previous years and, even though it decreased in the two next years, it grew again and keeps to be high since then (see Figure num. 1). In the media, the news about the rising Mediterranean migration both influenced and reflected the public opinion that the migrant inflow unlocked a crisis because the policy-makers missed to protect the economic, cultural and physical security of the citizens against the migrants ${ }^{34}$. The media missed to inform about the conditions that forced people to leave their home in large areas of Africa and the Arab world, and diffused the argument that the growing irregular migration was mostly the result of disorder in the North African countries because of the Arab Spring. For sure political events in the Arab countries interrupted the existing order, created uncertainty, and pushed many people to leave. Moreover, the removal of colonel Gadhafi from power in Libya removed the obstacle to the departure to Italy of the migrants from Sub-Saharan Africa. In 2009, to comply with the EU claim and the external migration policy, the

34 ATtinÀ, F. and Rossi, R., "The citizens feedback on the EU management of the migration crisis», in Moccia, L. and Pop, L. (eds.), Migrants and Refugees across Europe. How to share the challenge for a shared world of peace, Berlin, European University Press, 2017, pp. 19-58. 
prime minister of Italy, Silvio Berlusconi, had signed with Qaddafi the treaty that exchanged Italian money for blocking African migrants into the Libyan territory ${ }^{35}$.

The North European governments and mainstream parties blamed the Southern partners for impairing the EU Schengen system by missing to control the external borders. The growing number of sinking boats full of migrants and the fatal accidents in the Mediterranean seawaters did not stop the Commission and the Council from reaffirming the need of enforcing the existing rules of no entry of non-EU nationals that lacked regular permit. Last, all governments agreed to consider irregular immigration as a trans-boundary issue to manage at the EU level by coordinating the national responses and by common management actions.

Managing a crisis is doing a set of actions aimed at addressing the threat that provoked the break in the system life in order to restore normal conditions. In a trans-boundary crisis context, the tasks to be accomplished to manage the crisis must be shared by the political leaders of the affected countries. They have to choose the common management strategy and coordinate actions. Boin, Ekengren, and Rhinard ${ }^{36}$ drew up from the literature on collective risk management ${ }^{37}$ a list of tasks the political leaders of the affected countries have to accomplish for the effective and legitimate management of the trans-boundary crisis. In the remaining part of the present section, the management decisions and actions of the EU institutions and governments are briefly examined while in the next section the EU management is assessed by reviewing how the leaders accomplished the tasks of trans-boundary crisis management.

From the 2011 increasing to the present time decreasing inflow of irregular migrants in Europe and the containment of the wave of migrants in North African countries (Figure num. 1), the management of the migration crisis by the EU institutions and governments has gone through different stages and little change. From the belief in the efficacy of the conventional response to the present unanimous reliance on border control and partnership agreements with the governments of the origin and transit countries, the EU management objectives and tools have not really changed in nature and the governments have not rejected the principles of the immigration regime the EU institutions lastly approved in 2011. The attitude of the governments towards cohesion in the execution of the common management actions, instead, went through ups and downs and has been generally overwhelmed by fragmentation and division.

35 AttinÀ, F., «Italy and the European migration crisis», in Colombo, A. and Magri, P. (eds.), The age of uncertainties. Global scenarios and Italy, Milano, Edizioni Epoké-ISPI, 2017, pp. 151-160.

36 Boin, A., Ekengren, M., and Rhinard, M., The European Union as crisis manager: Patterns and prospects, Cambridge, Cambridge University Press, 2013.

37 See the recent review by Nohrstedt, D., Bynander, F., Parker, C. and Hart, P., «Managing Crises Collaboratively: Prospects and Problems-A Systematic Literature Review», Perspectives on Public Management and Governance, 2018, pp. 1-15. 
Figure num. 1. Irregular border crossing: Mediterranean routes

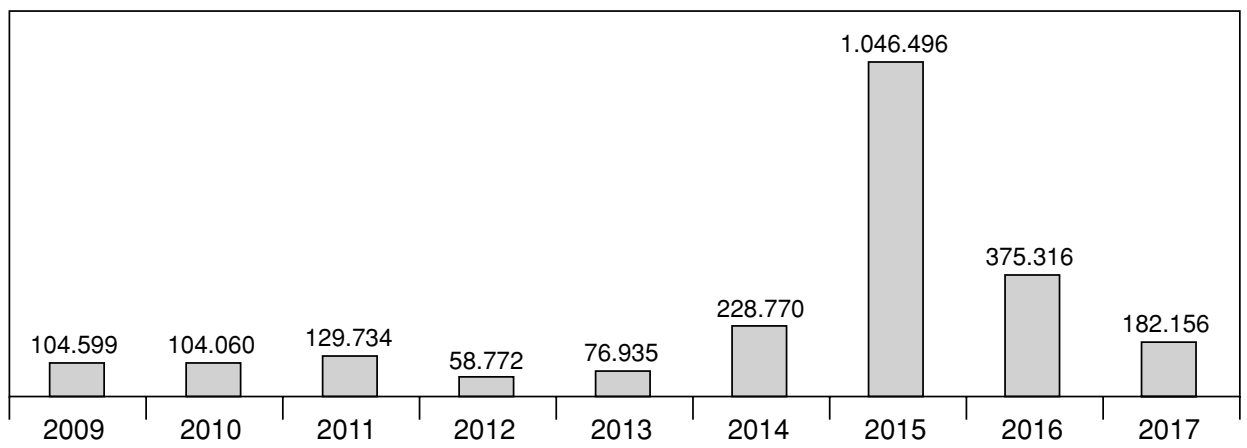

Source: http://frontex.europa.eu/trends-and-routes/migratory-routes-map/(accessed 30.01.2018).

The analysis of the negotiation and decision at the EU level since 2011 reveals five phases of management. Each phase is a particular scenario or configuration of actors, issues, and events that influenced the making of the common management ${ }^{38}$. The five-step process demonstrates the difficult building of the management of a trans-boundary crisis since the politics and society of the countries affected by the crisis do not share values, interests and expectations about the issue at stake and about the threats and uncertainties emerging from the crisis condition. The five phases are briefly described as follows.

2011 - September 2013: the conventional response phase. The outbreak of the Arab Spring in the North African countries removed the existing obstacles to the flows of people that chose to escape hard conditions of living in Africa and Central-Western Asia by travelling through North Africa and crossing the Mediterranean to reach Europe. The European political leaders and the EU institutions did not accept that they had to face a mass migration wave in which forced migrants took over irregular economic migrants. They responded to the increasing mixed migration by restating conventional border control as the means to contain the entry of irregular economic migrants, and by reasserting the duty of the MS governments to comply with the rules of halting, identifying, and returning to the home country the migrants lacking regular visa.

October 2013 - October 2014: the Mare Nostrum phase. A different scenario started from the Italian government decision to prioritize emergency rescue in consonance to humanitarian law and the international law of the sea in responding to the risk and distress of the migrants crossing the Mediterranean abroad precarious boats. Therefore, the Italian government launched the Mare Nostrum operation to carry out Search and Rescue (SAR) tasks in

38 Attinà, F., op. cit. nota 12, 2016, p. 7, and AtTinà, F., EU Management of Migration Crisis: Policy responses from Italy, Izmir, Yasar University, UNESCO Chair on International Migration Policy Brief, 2018, num. 1 . 
line with the international law of the sea and border control tasks including stopping and taking to justice the smugglers of migrants. The EU and partner governments condemned the operation and blamed the Italian government for endangering the Schengen system. All the Italian political parties, also those opposing the rescue operation, asked to the EU and the MS governments to take on themselves the burden and costs of the reception of the migrants that wanted to reach North Europe.

November 2014 - September 2015: the comprehensive approach phase. A year after Italy started Mare Nostrum, the EU governments and the Commission recognized the humanitarian aspects of the unsafe crossing of the Mediterranean Sea, and turned towards, they said, a comprehensive approach. This involved the EU SAR operation Triton that had engagement rules smaller than that of Mare Nostrum; the plan to relocate to all the EU countries the migrants hosted in Greece and Italy that ended in a fiasco ${ }^{39}$; and the EUNavFor-Med anti-smuggling operation that did not reach any tangible result. The Commission and the Council declared the will to address the root causes of migration, i.e. the global and local drivers and incentives of migration, by funding apposite anti-migration projects in the outflow countries. The British and the Visegrad governments overtly opposed the new approach that was doomed to a short life. The consent of the other EU governments was rather elusive. Since that time, each government has tailored the implementation of the EU management decisions on domestic interests and the people opinion about migration.

October 2015 - January 2017: the Fencing-the-EU phase. In summer 2015, the massive arrival of migrants and mostly of Syrian refugees through Turkey and the Balkans, known as the Eastern Mediterranean route, convinced the EU governments to go back to the conventional border control. The Council President, Donald Tusk, invited the migrants not to «dream» about Europe. The Commission spoke loudly on the appropriateness of the GAMM-outlined external migration policy, and reproached the governments for the feeble support to that common policy. To get Europe rid of refugees and migrants, the EU institutions and governments called on the governments of the transit and origin countries to block people at their borders, and promised granting funds and technical assistance to raise their capabilities of border control. On March 2016, the EU governments signed the (in)famous accord with Turkey, also known as the EU-Turkey deal, that gave huge EU and MS funding to the Turkish government in exchange for blocking the departure to Greece and sending back to Turkey the irregular migrants and Syrian refugees. On next October and December, the EU signed a migration compact and a partnership agreement respectively with the Lebanon and Jordan government. Later, similar engagements have been made with the Afghanistan and African gov-

39 The 2017 December meeting of the European Council took note of the failure of the plan consequent to the small compliance by the MS governments. The Council decided to review the plan at the next meeting on May. 
ernments. The EU-Turkey deal saved Germany, the Central-Eastern MSs, and the non-EU countries of the Balkans from the influx of refugees coming from Syria, Afghanistan, Yemen and the Horn of Africa, and from the influx of forced and irregular migrants from other areas. To the EU leaders, the huge fall of the number of migrants that followed the shutting down of the Eastern Mediterranean route was evidence of the appropriateness of the fencing-theEU strategy and of the migration partnership with third countries, especially with the countries of last departure of the migrants. On such belief, in October 2016, the EU governments acceded to the Commission proposal to give to FRONTEX the task of acting as the European border and coast guard, in reality of acting as the coordinator of the border and coast guard agencies of the MSs. Yet, in earlier September, Austria, Germany, and Slovenia had introduced temporary control at their borders pursuant to the Schengen Borders Code $^{40}$.

February 2017 on: the Stop-and-return phase. Besides almost ending immigration through the East Mediterranean route, the main return of the EU-Turkey deal was the growth in number of migrants leaving to Italy from Libya. The EU leaders urged Italy again to tighten border control and raise the number of the return of irregular migrants to the origin country. In turn, the EU was ready to expand financial and technical support to Italy for border control, hotspots, and anti-immigration actions. The Italian government agreed to tighten border control, expand the execution of return decrees, and, most important, cut down smuggling by giving financial and technical assistance to the Libyan coast guard and by imposing a code of conduct on the NGO-operated SAR missions after taking into account the failure of the CSDP operation against the smuggling organisations. EU on turn added funding and technical assistance to Libya for totally ending the departure of migrants, a goal not yet achieved as of today (June 2018).

In conclusion, the making of the common management has been a long and contentious process. The decisions of the European Council have met with the feeble and sometimes distorted implementation by the national governments, and the de facto rejection by the Visegrad governments. At the end of the process, all the governments have met on the tightening of the border control measures and the practice of signing migration partnership agreements with the origin and transit countries. These are indeed the pillars of the GAMM policy for promoting well-managed economic migration.

The burden of responding to the still active mixed migration wave has been put largely on the shoulders of the frontline states, today essentially of Italy. Irregular migrants continue go through the external and internal borders of the EU countries, and the national governments continue to manage the situation mostly on their own, by their own standards and objectives

40 They have been joined by other states. As of March 2018, Austria, France, Germany, Denmark, Sweden, and Norway continue to make use of the Schengen Borders Code that allow to extend temporary control up to a two-year period. 
while the media from time to time inform about the irregular movement of persons across Europe, the hardship the irregular migrants inside and outside hotspots and centres, and the death of children and adults in the Mediterranean waters ${ }^{41}$.

\section{ASSESSMENT OF THE EU MIGRATION CRISIS MANAGEMENT}

The mass migration wave towards Europe keeps bearing on the EU countries while governments and the Commission remain true to the GAMM paradigm of well-managed migration as if the current wave is just a wave of economic migrants. The objective of the present section is to assess how, through the five phases of the building process, the EU political leaders have agreed upon and managed the common response in order to restore the pre-crisis situation or, at least, moderate the impact of the crisis. The assessment addresses the tasks the political leaders have to carry out to respond to a trans-boundary crisis by an effective and legitimate management ${ }^{42}$.

The task of detecting the crisis in due time is of utmost importance to the rapid solution of the crisis. Up to the last quarter of 2014, the EU governments and institutions did not detect the mixed nature of the migration wave and claimed they were facing the arrival of economic migrants that violated immigration laws. In autumn 2014, the EU leaders recognized both the humanitarian emergency inherent in the Mediterranean crossing of the migrants abroad unsafe boats and the need to change the conditions that cause the migration wave. Consequently, they decided to replace the conventional response by the comprehensive approach response. But this recognition of the nature of the phenomenon and the pledge to revise the approach did not reverse the EU management model of the crisis.

Sense-making is the task of collecting, analysing and sharing information to generate the common representation of the situation. The EU leaders refused the alerts of the experts about unemployment, overpopulation, and violence as the source of the increasing wave of persons that are determined to go unlawfully through state borders to solve their life problems. The EU leaders' making sense of the Mediterranean migration flows as the unauthorised movement of economic migrants is stated in the 2011 Global Approach to Migration and Mobility and restated in the European Agenda for Migration that was prepared by the Commission and approved by the Council in 2015 to pledge support to the migrants but in reality to draw the line of the strict border control around the humanitarian rescue and search actions.

Joint decision-making is at the core of the common management of a trans boundary crisis. The leaders of all the EU states have been involved in the

${ }^{41}$ Vollmer, B. A., "The Continuing Shame of Europe: Discourses on migration policy in Germany and the UK», Migration Studies, vol. 5, 2017, num. 1, pp. 49-64, and SouIRE, V., op. cit. nota 3, p. xx.

42 Boin, A., Ekengren, M. and Rhinard, M., op. cit., nota 36, p. xx. 
decision-making of the common management. The European Council, as the top policy-making institution of the EU for the most acute problems, selected priorities and addressed the management guidelines to the Council and the Commission. These institutions and the MSs departments and ministries have prepared the official decisions and have led the execution of the management actions. The whole decision-making process never was a smooth and swift process. There have been delays and postponement as well as ambiguities. Before the meetings of the European Council, the heads of government that were less inclined to share management used to inform the media about their disagreement with the proposals on the table. Though they did not block the agenda of the meeting, later on they frustrated the common management efforts by declining to act partially or totally in compliance with the Council Conclusions.

Identifying key partners and facilitating coordination brings resources and know-how to the common management. The MS governments sought the collaboration of the partners that were essential to face the problems of accommodating irregular migrants like the local community authorities and civil society organizations. The Council and the Commission, instead, worked mainly to build a network of Non-EU partners to share the management burden and, especially, to block the migrants outside the EU. Initially, the Non-EU Balkan countries have been requested not to drop migrants on the neighbours and to seal their border to the migrants. Later, the network of the external partners widened and comprised as different countries as Turkey, Lebanon, Jordan, and all the Central and Northern African countries. Coordination with these partners has been extended to long-term aid in view of tackling the root causes of the migration wave. The aid funds stem mainly from EU cooperation programmes that have been relabelled after the migration crisis like the EU Emergency Trust Fund for Africa, the Facility for Refugees in Turkey, and the EU Regional Trust Fund in Response to the Syrian Crisis ${ }^{43}$.

Generally, the governments of the African states ineffectively accomplish the tasks that are stated in the agreements mainly because of the low efficiency of the public administration. Also the regional schemes proposed by the EU like the Rabat Process and the Khartoum Process did not produce notable results. Last, the partner network covers also international organizations, especially the UNHCR (Office of the United Nations High Commissioner for Refugees) and the IOM (International Organization for Migration), and humanitarian non-governmental organisations ${ }^{44}$. These partnerships supply the management but hardly take it to the final results.

Meaning-making is the task of devising a clear explanation of how the response actions match to the threat and how the leaders are in control of the

43 Den Hertog, L., Money talks. Mapping the funding for EU external migration policy, CEPS Papers in Liberty and Security in Europe, 2016, num. 15.

44 Irrera, D., Migrants, the EU and NGOs: "The "Practice" of Non-Governmental SAR Operations», Romanian Journal of European Affairs, vol.16, 2016, num. 3, pp. 20-35, and IRRERA, D., EU emergency response policies and NGOs, Basingstoke, Palgrave, 2018. 
situation. The collective messages of the EU institutions and political leaders to the citizens aimed at reassuring about the effectiveness of the decisions to bring the crisis to an end but, generally, the messages of the individual governments were different from those of the Commission and the European Council. Consequently, the citizens perceived the lack of a common vision about the nature of the threat in addition to the low compliance by the common decisions. This frustrated the citizens' trust on the leaders ability to control the threat and manage the crisis by acting as a single entity while increased the citizen trust on the leaders that challenged the common management.

The communication task is aimed at delivering clear messages to the relevant audiences. Generally, communication about the nature of the migration wave and the common response has been lacking of consistency and homogeneity. The national leaders made use of all the mass media and social networks to inform the citizens about the concern and actions for managing the crisis. The President of the Commission and the President of the European Council acted as the main EU information sources about the common management. The President of the European Council sent messages also to the migrants and advised them not to travel to Europe because Europe has not the opportunities they are looking for and the European countries do not accept the violation of the rules of border crossing. On occasion, the President of the Commission addressed the MS governments to express disappointment for the missing compliance with the decisions of the Council.

Accountability is the task of going to the official and public fora to report about the management decisions and actions for receiving the approval or rejection of the citizens. Generally, the crisis has been far from turning on political conflict in the parliaments of the European Union and the member countries. The European Parliament members broadly trusted the approach of the European Council and the Commission, and approved at large majority the common management decisions and actions. Also the debates in the national parliaments did not put the national governments in a quandary. The mainstream parties did not challenge the anti-immigration movements, did not back the views of groups favourable to the integration of migrants in the country, and did not share the expert view about forced migration. Despite the neutral approach adopted by the mainstream parties, the voters have rewarded the anti-immigration parties at the polls during the time of the crisis.

In brief, the EU political leaders did not pay timely attention to the increasing wave of migrants and refused to listen to the expert information about the mixed nature of the flow. The process for joint decision-making and the co-management of the crisis has been always in action but the implementation of the decisions has been partial and fragmented to respond to the preferences of the government and the voters of each member state. Communication has been poorly addressed to meet the goal of raising the consent of the citizens while accountability has been almost lacking within a tacit and widespread consent to anti-immigration rules. 


\section{CONCLUSIONS}

The European governments managed migration as a normal phenomenon in the past through national policies and by developing a common regime within the European Union that goes along the national immigration regimes. The common and national regimes and policies have been developed for governing separately economic immigration issues and the protection of asylum-seekers. The increasing wave of mixed migration that almost thirty years ago the experts brought to knowledge remained stranger to the European policy-makers and the wider public. They have turned a blind eye to it and its causes and drivers even when the wave hit the Southern European shores and the Mediterranean sea with tremendous human tragedies. The tenacious determination of the policy-makers to manage the mixed migration wave by the instruments of the economic migration policy and the prevailing hostile response of the citizens that in the post-2008 economic rundown perceived all migrants and refugees as a threat to the economic, cultural and security conditions of their country resulted in responding to the migration wave by building national and common crisis management strategies aimed at achieving zero or quasi-zero entry of migrants into Europe.

The present article has examined the making of this response by the European political leaders that ended in a shared management model oriented to all-out preventing immigration. The national management policies remained largely unaltered and restrained the EU role to supporting their border control measures through FRONTEX, EASO, and small technical and financial assistance. It also limited the EU action aimed at facilitating intergovernmental agreements in the field of migration through the external migration policy and the technical and financial assistance to the border control capabilities of the origin and transition countries. The article has drawn attention to the weaknesses of this management model that should be the object of further study by policy analysts and migration experts. These weaknesses are summarized as it follows.

First, blocking the migrant entry does not address the causes of the pressure of migrants at the borders. Second, all-out restriction on immigration for the sake of blocking irregular migration does not fit to the need of lowskill workers that affect important sectors of the European economies like the construction and extraction, the agriculture and fishery, and the care, cleaning and catering sector. Third, the all-out restriction of immigration violates the European principles of open society and inclusive democracy, and has negative influence on the civil values of the European citizens. Additionally, it damages the reputation of the EU and the MSs as defenders of humanitarian values, human rights and international law, and as partners of the international organisations and non-governmental organisations involved in migration management. Fourth, cooperation with countries of origin and transit for blocking migration is useful to a small extent since 
non-compliance by the governments of these countries is encouraged by the benefits these governments draw from allowing migration. Fifth, cooperation with the countries of last departure has an impact on the reputation of the $\mathrm{EU}$ and the MSs since it exposes them to the accusation of human rights violation in complicity with the partner governments that do not care about the rights of the migrants who are not their citizens. Sixth, the migration compact funds have a short-term humanitarian effect but a small or no effect at all on the development and take-off of the economy of the receiving country since these funds do not affect the structures of the world market and do not hit the existing economic, trade, and financial regimes that preserve the stratification of the national economies as the sixty-year long history of the aid to development demonstrates.

\begin{abstract}
TACKLING THE MIGRANT WAVE: EU AS A SOURCE AND A MANAGER OF CRISIS

The response of the EU and Member States to the current migration wave is an interesting case of building collective management for coping with a trans-boundary crisis. The present article analyses and assesses the EU response to the migration wave in a wide perspective that encompasses the existing knowledge about the drivers of increasing migration and about Europe's political and social approach towards regular and irregular migrants in the past decades; the analyses of the response of the European leaders to the demand of the citizens to close off the borders and prevent migrants from getting in; and the assessment of the EU management of the crisis. The closing section checks the EU response against the drivers of the on-going migration wave and draws a picture of the main weaknesses of the EU response.
\end{abstract}

Keywords: European Union, migration policy, crisis management, border control, migration studies.

\title{
RESUMEN
}

\section{AFRONTANDO LA OLA DE INMIGRACIÓN. LA UE COMO CAUSA Y GERENTE DE LA CRISIS}

La respuesta de la UE y los Estados miembros a la actual ola migratoria es un caso interesante de desarrollo de una gestión colectiva para hacer frente a una crisis transfronteriza. El presente artículo analiza y evalúa la respuesta de la UE a la ola migratoria desde una amplia perspectiva que abarca tanto el conocimiento existente sobre los catalizadores del aumento de la inmigración así como la aproximación política y social de Europa hacia los migrantes regulares e irregulares en las últimas décadas; el análisis de la respuesta de los líderes europeos a la demanda de los ciudadanos de cerrar las fronteras y evitar que entren los migrantes; y la evaluación de la gestión de la crisis por parte de la UE. El ultimo apartado se centra en el análisis de la respuesta de la UE contra los impulsores de la presente ola migratoria y dibuja una imagen de las principales debilidades de la respuesta de la UE.

Palabras clave: Unión Europea, política migratoria, gestión de crisis, control fronterizo y estudios migratorios. 